\title{
Foreign body aspiration following unconven- tional use of a metered dose inhaler
}

\author{
Paolo Campisi MSc MD, * \\ Steven B. Backman MDCM PhD FRCPC, $\dagger$ \\ Robert Sweet MDCMFRCSC*
}

Purpose: Aspiration of a foreign body may be life-threatening. This report describes laryngeal obstruction after inhalation of a piece of a Turbuhaler ${ }^{\circledR}$ which resulted from a patient tampering with the device.

Clinical features: A 27-yr-old man disassembled a Turbuhaler ${ }^{\circledR}$ and inadvertently aspirated a plastic dispensing medication disc (22 $\mathrm{mm}$ diameter) while attempting to inhale the remnant terbutaline sulfate which accumulated on it. Although the patient was hoarse, he was not in acute respiratory distress. X-ray revealed the disc lodged in the larynx below the vocal cords. The patient was immediately transferred to an operating theatre, and a drying agent (glycopyrrolate), judicious sedation (midazolam and fentanyl) and $\mathrm{O}_{2}$ were administered. The airway was anesthetized with lidocaine $4 \%$ delivered using high-flow $\mathrm{O}_{2}$ through an atomizer. Direct laryngoscopy revealed a partially obstructed view of the disc lodged distal to the vocal cords which was inaccessible for retrieval. Loss of consciousness was subsequently induced by spontaneous mask ventilation with sevoflurane (in $\mathrm{O}_{2}$ ). The airway was visualized using a suspension laryngoscope and the foreign body was removed with grasping forceps. The patient was awakened, transferred to the ICU and given $4 \mathrm{mg}$ decadron iv every eight hours (two doses). Laryngoscopy prior to discharge indicated good mobility of the vocal cords and normal glottic structure.

Conclusion: Aspiration of a foreign body is a potentially life-threatening situation requiring coordination between anesthesiologist, surgeon, and nursing staff. Anesthetic goals include avoidance of upper airway obstruction and maintenance of adequate ventilation while the foreign body is retrieved. Provisions must be made for tracheostomy if these goals cannot be realized.

Objectif : L'aspiration d'un corps étranger peut être dangereuse. Dans le présent article, on décrit une obstruction laryngée survenue après l'inhalation d'une pièce de Turbuhaler ${ }^{\circledR}$, le patient ayant modifié l'appareil.

Éléments cliniques : Un homme de 27 ans a démonté un Turbuhaler ${ }^{\circledR}$ et aspiré par inadvertance un disque distributeur de médicament de $22 \mathrm{~mm}$ de diamètre en tentant d'inhaler du sulfate de terbutaline qui s'y était accumulé. Même si le patient était enroué, il ne présentait pas de détresse respiratoire aiguë. La radiographie a révélé la présence du disque dans le larynx, sous les cordes vocales. Le patient a été amené immédiatement en salle d'opération où il a reçu un médicament asséchant (glycopyrrolate), une sédation appropriée (midazolam et fentanyl) et de l' $\mathrm{O}_{2}$. Les voies aériennes ont été anesthésiées avec de la lidocaïne à $4 \%$ administrée à l'aide d'un atomiseur d' $\mathrm{O}_{2}$ à haut débit. La laryngoscopie directe a révélé une vision partiellement obstruée du disque logé sous les cordes vocales et inaccessible. La perte de conscience a été induite par la suite par la ventilation spontanée au masque avec du sévoflurane dans de l' $\mathrm{O}_{2}$. On a pu visualiser les voies aériennes en utilisant un laryngoscope à suspension et le corps étranger a été retiré avec des pinces à griffes. Le patient a été réveillé et transporté à l'USI. On lui a donné deux doses de $4 \mathrm{mg}$ de décadron iv à huit heures d'intervalle. L'examen laryngoscopique précédant le congé indiquait une bonne mobilité des cordes vocales et une anatomie glottique normale.

Conclusion : L'aspiration d'un corps étranger, potentiellement dangereuse, exige une intervention coordonnée de l'anesthésiologiste, du chirurgien et du personnel infirmier. Les objectifs anesthésiques sont de libérer les voies aériennes supérieures et de maintenir une ventilation adéquate. Si on ne peut y parvenir, on doit être en mesure de procéder à une trachéotomie.

From the Departments of Otolaryngology* and Anesthesia, † Royal Victoria Hospital and McGill University, Montreal, QC, Canada. Address correspondence to: Dr. S.B. Backman, Department of Anesthesia, Royal Victoria Hospital, 687 Pine Ave. W., Montreal, QC,

H3A IAl Canada. Phone: 514-842-1231 (Ext. 4880); Fax: 514-843-1723; E-mail: mdba@musica.mcgill.ca Accepted for publication May 6, 2000. 
A SPIRATION of a foreign body during use of a metered dose inhaler is a rare but recognized hazard. ${ }^{1-8}$ In these instances, small objects inadvertently lodged in the mouthpiece of an uncapped inhaler are aspirated upon forceful inspiration. This report describes an unusual case of laryngeal obstruction after inhalation of a piece of a Turbuhaler® which resulted from a patient tampering with the device.

\section{Case report}

A 27-yr-old well-nourished Caucasian man presented to the emergency room after he aspirated a part of his Bricanyl ${ }^{\circledR}$ Turbuhaler ${ }^{\circledR}$. The patient was a well-controlled asthmatic who had been using this device for several years and had become familiar with its design (Figure). As a considerable amount of powdered medication accumulates on the dispensing disc, following disassembly of the device, the patient would hold the powdered disc to his lips while inhaling vigorously. On this occasion, however, the disc was aspirated along with the powder. The patient's chief complaint was of voice hoarseness, and he denied shortness of breath or difficulty in swallowing. Although apprehensive, he did not appear to be in distress and was breathing quietly at a rate of $12 \mathrm{bpm}$. Bilateral decreased air entry, diffuse expiratory wheezing, and inspiratory stridor were audible upon auscultation of the chest. Examination of the airway was unremarkable with a clear view of the pharynx (Mallampati Class I). Antero-posterior and lateral soft tissue X-ray views of the chest and neck revealed a thin, circular object in the larynx at the level of the vocal cords. Pulse oximetry indicated a tissue oxygen saturation of $98 \%$ (room air). The patient had eaten approximately six hours before presentation.

The patient was transferred to the operating room with alacrity while preparations were made for a possible tracheostomy. With the patient in a supine position and breathing oxygen $100 \%$ via a loose-fitting clear plastic face mask, a drying agent $(0.3 \mathrm{mg}$ glycopyrrolate) and sedatives ( $1.0 \mathrm{mg}$ midazolam doses to a total of $4.0 \mathrm{mg} ; 50 \mu \mathrm{g}$ fentanyl doses to total $250 \mu \mathrm{g}$ ) were administered intravenously while giving meticulous attention to the patient's level of consciousness, respiration, and $\mathrm{O}_{2}$ saturation. The airway was anesthetized with lidocaine $4 \%$ delivered using high-flow oxygen through an atomizer. Direct laryngoscopy revealed a partially obstructed view of the glottic opening (Cormack Grade 2), and a portion of the plastic disc lodged just distal to the vocal cords which was considered to be inaccessible for retrieval. Pressure over the thyroid cartilage, which would undoubtedly have
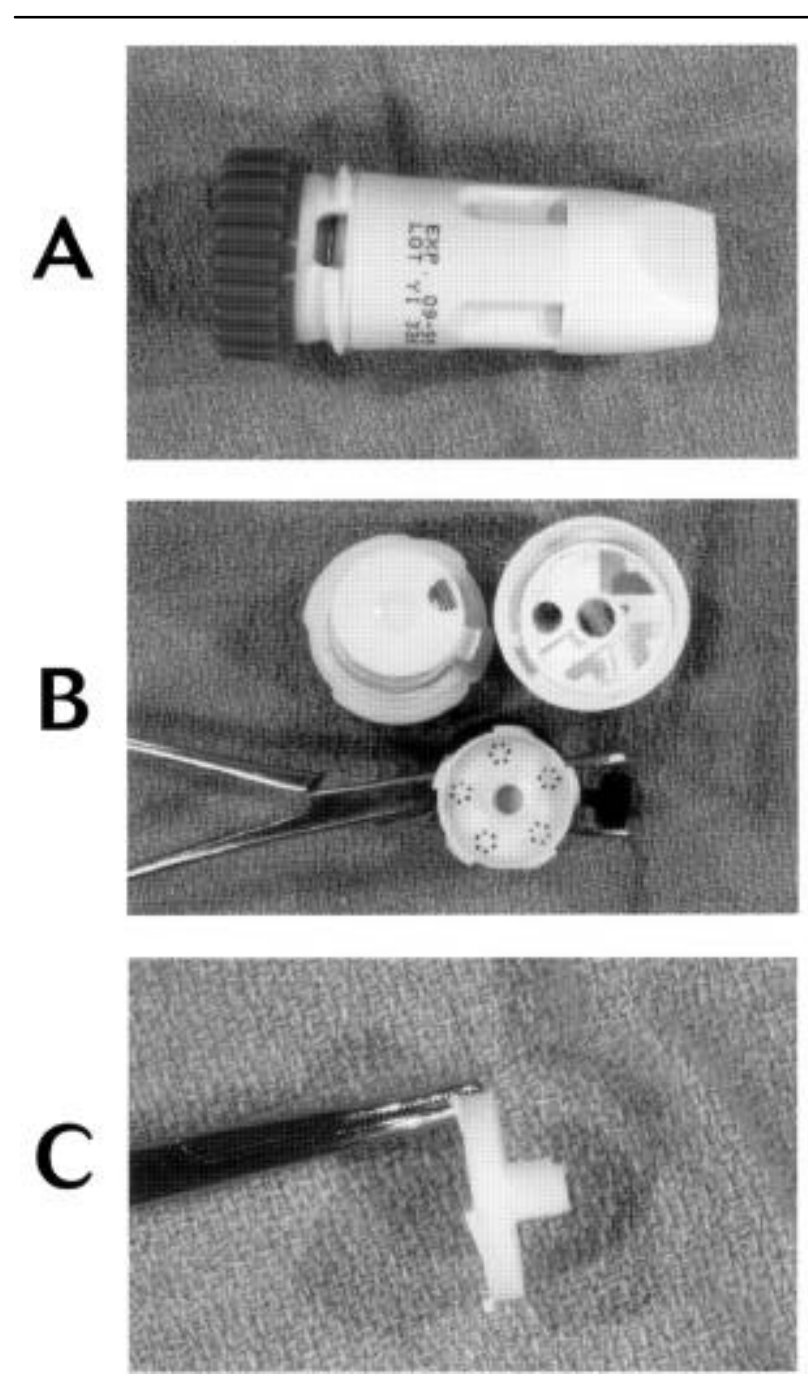

FIGURE Bricanyl® Turbuhaler® device intact $(\mathrm{A})$ and disassembled (B). Plastic dispensing medication disc is shown grasped in hemostat for face-on (B) and side (C) views. Disc measures 22 $\mathrm{mm}$ in diameter, and $10 \mathrm{~mm}$ thick at its centre (hub). Note the five sharp serrated edges. Disc was lodged just distal to patient's vocal cords, with its flat plane parallel to the patient's sagittal plane (i.e. view $\mathrm{C}$ observed through cords at laryngoscopy).

improved the view, was not attempted because of the possibility of worsening upper airway obstruction. Loss of consciousness was subsequently induced by spontaneous mask ventilation with sevoflurane (in oxygen $100 \%)$, starting with a low inspired concentration (1.0 $\%)$ which was gradually increased to help avoid apnoeic episodes. Following induction of loss of consciousness (end-tidal sevoflurane concentration 4-5\% maintained for approximately five minutes), the mask was removed from the patient's face, the airway was adequately visu- 
alized using a suspension laryngoscope and the foreign body was expeditiously removed with grasping forceps while the patient spontaneously breathed room air. As demonstrated in the Figure, the foreign body had serrated sharp edges around its circumference which held it firmly in place and created a near total obstruction of the glottis. The patient was awakened uneventfully, given oxygen via a loosely fitting face mask, and transferred to the ICU for monitoring because of possible upper respiratory obstruction secondary to edema. The patient received $4 \mathrm{mg}$ decadron $i v$ every eight hours (two doses), and laryngoscopy prior to home discharge indicated good mobility of the vocal cords and normal glottic structure.

\section{Discussion}

The Bricanyl ${ }^{\circ}$ Turbuhaler ${ }^{\circledR}$ (terbutaline sulfate) is a breath-activated multiple-dose powder inhaler. Thus, the patient inhales the drug without the assistance of a propellant. Each device contains 200 doses of drug $(0.5 \mathrm{mg}$ per dose $)$ and is not intended to be refilled. As with any metered dose inhaler, the Turbuhaler ${ }^{\circledR}$ should be stored with the cap in place and the mouthpiece checked for small objects prior to use. Misuse of the device, as described in the present report, poses a choking hazard and the potential for drug overdose resulting in excessive $B$-adrenergic stimulation. Most aspirated foreign bodies occur in children and become lodged in one of the mainstem bronchi. ${ }^{9-12}$ While the incidence of foreign bodies contained within the larynx is rare $(1-2 \%)$, laryngeal obstruction is more likely to cause death or hypoxic encephalopathy because of the inability to ventilate the lungs. In the present case, the foreign body was too large to have permitted its passage into a mainstem bronchus thus permitting ventilation of at least one lung. Maintaining spontaneous ventilation was of paramount importance and its loss may have precipitated calamitous airway obstruction. In such cases, airway obstruction could potentially worsen with patient excitement (e.g. forced respiratory efforts, coughing), excessive oral secretions or laryngeal manipulation (e.g. cricothyroid pressure, cricothyroid puncture with a needle for administration of local anesthetic). Apnea secondary to excessive anesthesia must be avoided. Sevoflurane was used for induction of loss of consciousness as it is non-irritating, acts rapidly and easily titrated. Provisions must be made for the possibility of a tracheostomy which would have been done in the event of complete airway obstruction, inability to maintain ventilation, or inability to retrieve the foreign body. Although considered not indicated in this case, one must evaluate the potential for extensive exploration of the trachea / bronchi requiring cardiopulmonary bypass for oxygenation. The risk of aspiration of gastric contents following the loss of protective airway reflexes must be balanced with the need for adequate airway anesthesia. Consideration should be given to the use of a non-particulate antacid, $\mathrm{H}_{2}$ blockers and agents to facilitate gastric emptying. ${ }^{2}$ Following removal of a foreign body, airway swelling may be diminished by nebulized racemic epinephrine. ${ }^{13}$ Helium-oxygen breathing mixtures reduce resistance to gas flow through stenotic areas and may be of some use postoperatively. ${ }^{14}$ Laryngeal foreign bodies must be addressed on an emergency basis requiring a coordinated effort between anesthesiologist, surgeon, and nursing staff. The present case report illustrates several important issues in managing such a potentially life-threatening situation. It also informs of the potential for dangerous misuse of the Bricanyl ${ }^{\circledR}$ Turbuhaler ${ }^{\circledR}$.

\section{References}

l Bray WR, Francis PB, Jacobs J, Burris AS. Two penny aspiration: unusual complication of a metered-dose inhaler (Letter). South Med J 1985; 78: 1527.

2 Li JTC, Gunderson D. Inhalation of the cap of a metered-dose inhaler (Letter). N Engl J Med 1991; 325: 431 .

3 Schultz CH, Hargarten SW, Babbitt J. Inhalation of a coin and a capsule from metered-dose inhalers (Letter). N Engl J Med 1991; 325: 431-2.

4 Wiesel JM, Bar ZG, Feinmesser R. Intrabronchial tablets - jet propelled. A case report. J Laryngol Otol 1981; 95: 219-20.

5 Taskar VS, Bradley BB, Moussali HM, Hilton AM. Foreign body aspiration: a hazard of metered dose inhalers. BMJ 1993; 306: 575-6.

6 McGonagle M, Reams CL. The jet-propelled "dime" (Letter). JAMA 1984; 251: 1431.

7 Hannan SE, Pratt DS, Hannan JM, Brienza LT. Foreign body aspiration associated with the use of an aerosol inhaler. Am Rev Resp Dis 1984; 129: 1025-7.

8 Cuckow PM, English TAH Foreign body inhalation: a danger of metered dose inhalers (Letter). J R Coll Gen Pract 1989; 39: 476.

9 Rothman BF, Boeckman CR. Foreign bodies in the larynx and tracheobronchial tree in children. A review of 225 cases. Ann Otol 1980; 89: 434-6.

10 Lima JA. Laryngeal foreign bodies in children: a persistent, life-threatening problem. Laryngoscope 1989; 99: 415-20.

11 Cohen SR, Herbert WI, Lewis GB Jr, Geller KA. Foreign bodies in the airway. Five-year retrospective study with special reference to management. Ann Otol 1980; 89: 437-42. 
12 Tasch MD, Stoelting RK Aspiration prevention, prophylaxis, and treatment. In: Benumof JL (Ed.). Airway Management Principles and Practice. St. Louis: MosbyYear Book Inc., 1996: 183-201.

13 Vender JS, Clemency MV. Oxygen delivery systems, inhalation therapy, and respiratory therapy. In: Benumof JL (Ed.). Airway Management Principles and Practice. St. Louis: Mosby-Year Book Inc., 1996: 205-27.

14 Doyle DJ, O'Grady K. Physics and modelling of the airway. In: Benumof JL (Ed.). Airway Management Principles and Practice. St. Louis: Mosby-Year Book Inc., 1996: 45-73. 